\title{
Standpunt
}

\section{Die Suid-Afrikaanse universiteitswese: koers in die krisis}

By die aanbreek van 'n nuwe millennium staan die universiteitswese wêreldwyd, en in Suid-Afrika in die besonder, op die breuklyn van beslissende veranderinge. Elkeen wat in ' $n$ akademiese hoedanigheid by universiteite in Suid-Afrika betrokke is, het die cise wat hierdic veranderinge stel, oor die afgelope dekade aan die lyf begin voel. Binne die brër Suid-Afrikaanse verband, waar die begrip "transformasie" die oorhecrsende slagspreuk geword het en skynbaar elke aspek van die SuidAfrikaanse leefwêreld in sy kielsog opsuig, was hoër onderwys in die algemeen, en universiteite in die besonder, reeds vrocë teikens van sowel die retoriek as dic praktyk van verandering. Daarvan getuig dic werk van die Nasionale Kommissic vir Hoër Onderwys (met hul verslag wat nie om dowe neute nie 'n "framework for transformation" genoem word!), die Witskrif wat hieruit voortgespruit het, dic nuwe Universiteitswet, nuwe beheerstrukture (soos die Raad op Hoër Onderwys en SAUVCA), die nuwe Nasionale Kwalifikasie-owerheid (SAKO of, soos meer algemeen bekend, SAQA) en, les bes, dic intensicwe beplanningsoefening rondom die nuwe onderrigprogrambedeling waarby alle Suid-Afrikaanse universiteite die afgelope drie jaar voluit betrokke is.

Daar kan geen twyfel daaroor wees dat die stelsel van hoër onderwys in Suid-Afrika drasties herbedink moes word nic. As stelsel was dit, met die aanvang van die nuwe politieke bedeling, kennelik te gefragmentecrd en te ontoeganklik vir die meerderheid van die bevolking wat daaraan kan meedoen en daaruit voordeel kan trek. Dit was daarby nie genoegsaam afgespits op die legitieme eise van ' $n$ snel veranderende omgewing nic. Die transformasie van hoër onderwys in Suid-Afrika is egter nie slegs die noodsaaklike uitloper van 'n sosiaal-politicke bedeling wat voorheen fundamenteel onregverdig en immoreel was nie. Tocvallig val die uur van groter politicke geregtigheid in die Suid-Afrikaanse universiteitswese ook saam met 'n uur waarin die universiteitswese internasionaal sigself bevind in ' $n$ stroomversnelling van radikale herkonsipiëring.

Laasgenoemde ontwikkeling hang met twee verskynsels saam. Die eersle is die mate waarin universiteit en samelewing hoe langer hoe nader aan mekaar beweeg. Dic tyd is eenvoudig verby dat die universiteit in relatiewe isolasie (as die sogenaamde "ivoortoring") van die res van die samelewing sy taak van wetenskapsbeoefening in terme van self-gegenereerde en selfgeformuleerde wetmatighede en standaarde volvoer. Daardie taak kan, gegee hedendaagse eise, eenvoudig nie meer uitgevoer word sonder grootskeepse steun van staatsweë (met belastinggeld) nie. Maar dis nie bloot ' $n$ kwessie dat dic samelewing vir dic universiteit en sy aktiwiteite betaal nie. Die persepsie groei daarby dat wat aan die universiteit gedoen word, van regstreekse belang vir die samelewing is. Die verwagting is ook dat mense deur die universiteit "geproduseer" word wat oor sekere vaardighede beskik waarsonder die moderne ekonomie nie kan funksioneer nie. Vandaar die klem op sogenaamde "hoëvlakmensekrag" en "uitkomsgebaseerde onderwys".

Die tweede aspek is egter die wyse waarop die samelewing waarin universiteitsafgestudeerdes hulself deesdac bevind, self, veral in 'n ekonomiese sin, getransformeer is. Dis 'n samelewing wat toenemend byvoorbeeld ontdek dat welvaart nie meer te vinde is in geproduseerde goedere nie, maar in sogenaamde "nietasbare" verskynsels, soos inligting, kreatiwiteit, vindingrykheid, konneksies, ens. Dic grootste welvaartskeppers van ons samelewing is byvoorbecld inligtingstegnologic-maatskappye wat selde artikels produseer (soos die Fords en General Electries en Nestlé's van weleer), dog wat ecrder "produkte" skep wat mense bemagtig om oor die weg te kom in 'n milieu waarin die werklikheid toenemend gesimuleer word, waarin "middel-mense" en -instansics (bv. verkoopsagente, winkels, reisagente, ens.) uitgeskakel word, en waarin ekonomiese waarde dikwels gemeet word aan die vermoë van webwerwe om die aandag van potensiële kopers en kliënte te trek.

Die aanname van die samelewing is eenvoudig dat universiteite op hierdie veranderde milieu moet inspeel en mense moet voorberei om in hierdie wêreld nic alleen oor die weg te kom nie, maar om bydraes te lewer om hierdic wêreld meer gestroomlyn en effektief te maak. Vandaar die meedoënlose aandrang om nie alleen universiteitsonderrig te plooi in die rigting van beroepskole wat pragmatiese afrigting vir afgestudeerdes bied nie, maar om ook navorsing sentraal te beplan en te stuur deur middel van, byvoobeeld, die onlangs aangekondigde "voorkeurareas" wat die Nasionale Navorsingstigting (NNS) voortaan uitsluitlik sal befonds. So word een of ander sentraal gekonsipieerde idee van die algemene belang op die universiteitswesc afgedwing, en word, met die roede van die beursie, akademici gedwing om in pas te kom met wat geag word as van algemene belang.

In hierdie klimaat is daar ' $\mathrm{n}$ dringende eis aan universiteite om nie meegesleur te word in die ideologic van korttermyndienstigheid nie. Die universiteit as beliggaming van die strewe van die liefde vir die waarheid en die wysheid ("amor sciendi") moet aandring op 'n ruimte waarin dic onbevange soeke na waarheid gerespekteer word. Die universiteit as instelling het sy bydrae in die verlede gelewer omdat dit 'n sentrum vir "kritiese diskoers en ongesensurecrde vraagstelling, vir reflektiewe afstandneming en onafhanklike ondersock, vir vrye eksperimentering en kreatiewe verbeclding" was (H.W. Rossouw). Só beskou word 'n universiteit 'n merkteken vir beskawing. 'n Beskawing is onvoorstelbaar, sê Hennie Rossouw tereg, "sonder 'n institusionele ruimte waar heersende waardes en ortodoksieë vrylik en vreesloos geëksamineer en getoets word, en waar nie net die korttermynbehoeftes van dic mark en dic werkplek intellektuele aandag geniet nie, maar ook kritiese vrae oor die soort samelewing en die soort doelstellings wat hierdie behoeftes genereer". Slegs 'n samelewing wat ruimte maak vir universiteite in hierdic sin kan aanspraak maak op dic titel "beskawings", en dan wel waar die begrip "beskawing" gebruik word in die sin waarin Alfred North Whitehead dit gebruik het: "the victory of persuasion over force". 